\title{
Archaeological Monitoring in Connection with the San Antonio Wastewater Facilities Improvements Program, San Antonio, Bexar County, Texas
}

Anne A. Fox

I. Waynne Cox

Follow this and additional works at: https://scholarworks.sfasu.edu/ita

Part of the American Material Culture Commons, Archaeological Anthropology Commons, Environmental Studies Commons, Other American Studies Commons, Other Arts and Humanities Commons, Other History of Art, Architecture, and Archaeology Commons, and the United States History Commons

Tell us how this article helped you.

This Article is brought to you for free and open access by the Center for Regional Heritage Research at SFA ScholarWorks. It has been accepted for inclusion in Index of Texas Archaeology: Open Access Gray Literature from the Lone Star State by an authorized editor of SFA ScholarWorks. For more information, please contact cdsscholarworks@sfasu.edu. 


\section{Archaeological Monitoring in Connection with the San Antonio Wastewater Facilities Improvements Program, San Antonio, Bexar County, Texas \\ Creative Commons License \\ (c) (1) (9)}

This work is licensed under a Creative Commons Attribution-NonCommercial 4.0 International License 
ARCHAEOLOGICAL MONITORING IN CONNECTION WITH THE SAN ANTONIO WASTEWATER FACILITIES IMPROVEMENTS PROGRAM, SAN ANTONIO, BEXAR COUNTY, TEXAS

Anne A. Fox and I. Waynne Cox

Center for Archaeological Research The University of Texas at San Antonio® Archaeological Survey Report, No. 194 
The following information is provided in accordance with the General Rules of Practice and Procedure, Chapter 41.11 (Investigative Reports), Texas Antiquities Committee:

1. Type of investigation: archaeological testing and monitoring of sewer line routes for San Antonio Wastewater Facilities Improvements Program;

2. Project name: Packages G, H, and I;

3. County: Bexar;

4. Principal investigator: Jack D. Eaton; coprincipal investigator: Anne A. Fox;

5. Name and location of sponsoring agency: City of San Antonio, Department of Environmental Management, c/o PD VA Group, 9310 Broadway, San Antonio, Texas 78217;

6. Texas Antiquities Committee Permit No. 655;

7. Published by the Center for Archaeological Research, The University of Texas at San Antonio, San Antonio, Texas 78285-0658, 1990.

This book is printed on acid-free paper (Cougar No. 1 Opaque Offset).

A list of publications offered by the Center for Archaeological Research can be obtained by sending $\$ 1.00$ to the Center for Archaeological Research, The University of Texas at San Antonio, San Antonio, Texas 78285-0658. 


\begin{abstract}
During 1987-1988, archaeologists from the Center for Archaeological Research monitored the excavation of trenches for new sewer pipelines within the Mission Parkway Historic/Archeological District in south San Antonio. In locations where the trenches crossed the mission acequias, boring was conducted to carry the line beneath the channel. At the site of an auxiliary building on the Hot Wells Hotel property, the cutting of a trench was monitored, and foundation wall lines were documented by photography and measured drawings.
\end{abstract}




\section{TABLE OF CONTENTS}

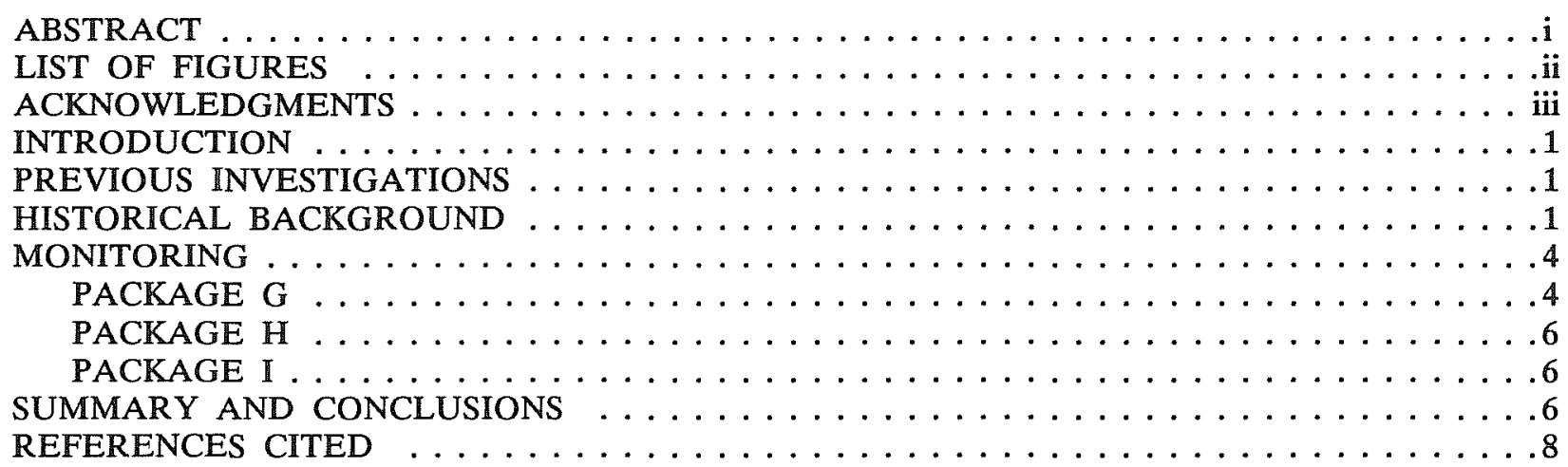

\section{LIST OF FIGURES}

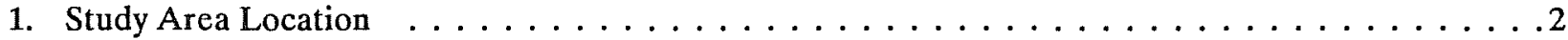

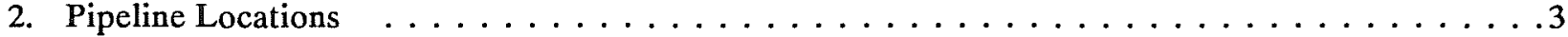

3. Location of the Auxiliary Building on the Hot Wells Hotel Property . . . . . . . . . . . .4

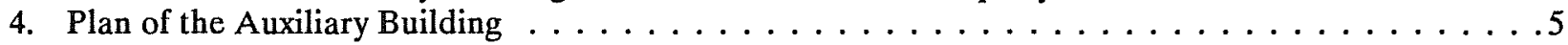

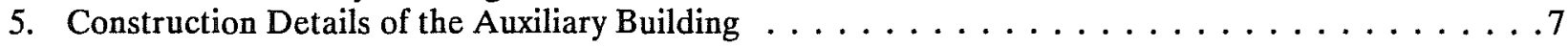




\title{
ACKNOWLEDGMENTS
}

The following people from the PD VA Group have helped expedite our work at various times and locations:

\author{
Salah Diab \\ Joseph Fortier \\ Mary Bell Haney \\ Michael Janowski \\ Greg Morgan
}

\author{
Mary Randall \\ Larry Rein \\ Don Vandertulip \\ Mike Waring
}

We would also like to thank Frank R. Kiolbassa, director, Department of Environmental Management, City of San Antonio, Hayden Whitsett of the Texas Water Development Board, and José Cisneros and Stephen Adams of the San Antonio Missions National Historic Park for their help and cooperation in planning and carrying out our small part in this large and essential project.

UTSA graduate students Maureen Brown and Curt Harrell were members of the archaeological crew who helped document the trenching at the Hot Wells Hotel property. Maureen Brown, Mary Ossi, and Frances Meskill drafted the maps and drawings for this report, and Harrell was photographer for this project. 



\section{INTRODUCTION}

In August 1987, the Center for Archaeological Research (CAR), The University of Texas at San Antonio (UTSA) entered into a contract with the City of San Antonio to do archaeological monitoring of construction of three sections of pipeline (Packages $\mathrm{G}, \mathrm{H}$, and $\mathrm{I}$ ) included in the San Antonio Wastewater Facilities Improvements Program. The monitoring was to be done at selected locations where pipeline construction could possibly impact known historical cultural resources. The location of the project area is indicated on Figure 1. The area is within the Mission Parkway Historic/Archeological District. Texas Antiquities Committee Permit No. 655 was issued for the project.

At Package G (RR-106B), the monitoring was to cover the entire length of the line as it crossed the Hot Wells Hotel property (41 BX 237). Spot checking was to be done throughout the excavation of the line across the adjoining property to the south which belongs to the San Antonio State Hospital.

At Package H (RR-106A), monitoring was to be done of the operation of boring beneath the San Juan acequia south of Pyron Road. In addition, the trench for the pipeline was to be monitored where it crossed the line of the dam for the Espada acequia.

At Package I (RL-2), archaeological monitoring was planned where the pipeline trench crossed the line of the San José acequia, somewhere near the location of the Mission Funeral Home. At Package I (RL-9), monitoring was to be done of the boring for the pipeline beneath the Espada acequia.

Principal investigator for the project was Jack D. Eaton, acting director of the CAR. CAR research associate Anne A. Fox served as coprincipal investigator and project director. The monitoring was to be done by Fox and CAR research associate $I$. Waynne Cox, aided where needed by UTSA archaeological students. The monitoring was done during brief periods in October 1987, and January 1988, and on a regular basis during April and May 1988.

\section{PREVIOUS INVESTIGATIONS}

The CAR has been involved in the archaeological clearance for the San Antonio Wastewater Facilities Improvements Program (originally entitled San Antonio 201 Wastewater Treatment Project) since 1976. This has involved archaeological survey and testing along the routes of proposed new sewer lines and improvements to the existing system throughout the city (Fox 1977; Fox, McGraw, and Valdez 1978; Assad 1979; Snavely, Greco, and Fox 1984) and monitoring as construction projects were begun (Hafernik and Fox 1984; Cox 1988) as recommended in the Plan for Mitigation submitted by Fox (1979).

Other archaeological projects in the general area, outside of work at individual mission sites, have included a detailed survey of the Mission Parkway (Scurlock et al. 1976), testing at the site of the Hot Wells Hotel (Fox and Highley 1985), and recent investigations of the San Juan dam (Cox, Fox, and Scott 1989).

\section{HISTORICAL BACKGROUND}

The area through which the pipelines in Packages $G, H$, and I run is part of the lands originally owned and cultivated by Missions Concepción, San José, San Juan, and Espada (Rotchford n.d.). The dams for the San Juan and Espada acequias (irrigation ditches) are also included within and directly related to the area, as are large portions of those acequias (Fig. 2).

The dams and acequia systems for the San Antonio missions were constructed in the early 18 th century to provide irrigation for the mission fields, where crops were grown to feed the mission inhabitants. The acequias were open, mud-lined ditches, and several continued to carry water for irrigation after the mission period. The Espada acequia system on the west side of the river is still in partial use today. The San Juan system has been dry for a number of years but still has miles of open ditches that run along the east side of the river. The National Park Service has announced plans to put this acequia back into use as part of its interpretive program. The San José acequia apparently went out of use soon after the close of the mission period and is now buried and its exact location forgotten. However, it is possible to estimate the acequia's route through the use of maps and deed records.

The following historical background on the Hot Wells Hotel is summarized from research done by Fox and Highley (1985:4-19) for test excavations at the hotel site in 1984.

When the San Antonio State Hospital was opened in 1892, the well for the facility was found to yield warm $\left(103^{\circ} \mathrm{F}\right)$ water with a strong odor of sulphur. Local entrepreneurs soon capitalized on this discovery by opening a resort somewhere near the asylum in 1893, leasing the water from them. A large bathhouse was constructed in a parklike setting. In December 1894, the bathhouse was destroyed in a fire. In 1900, another group of San 


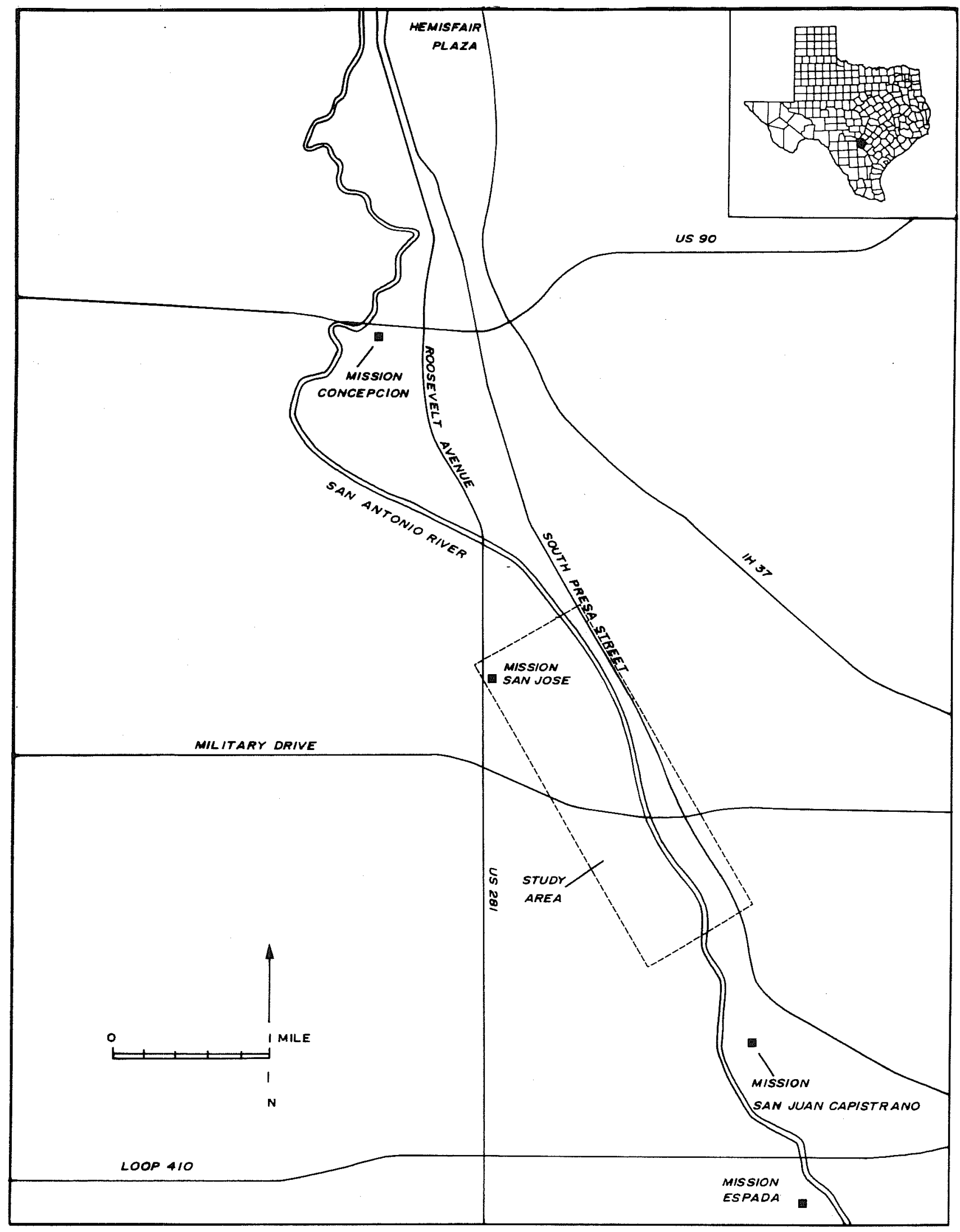

Figure 1. Study Area Location. 


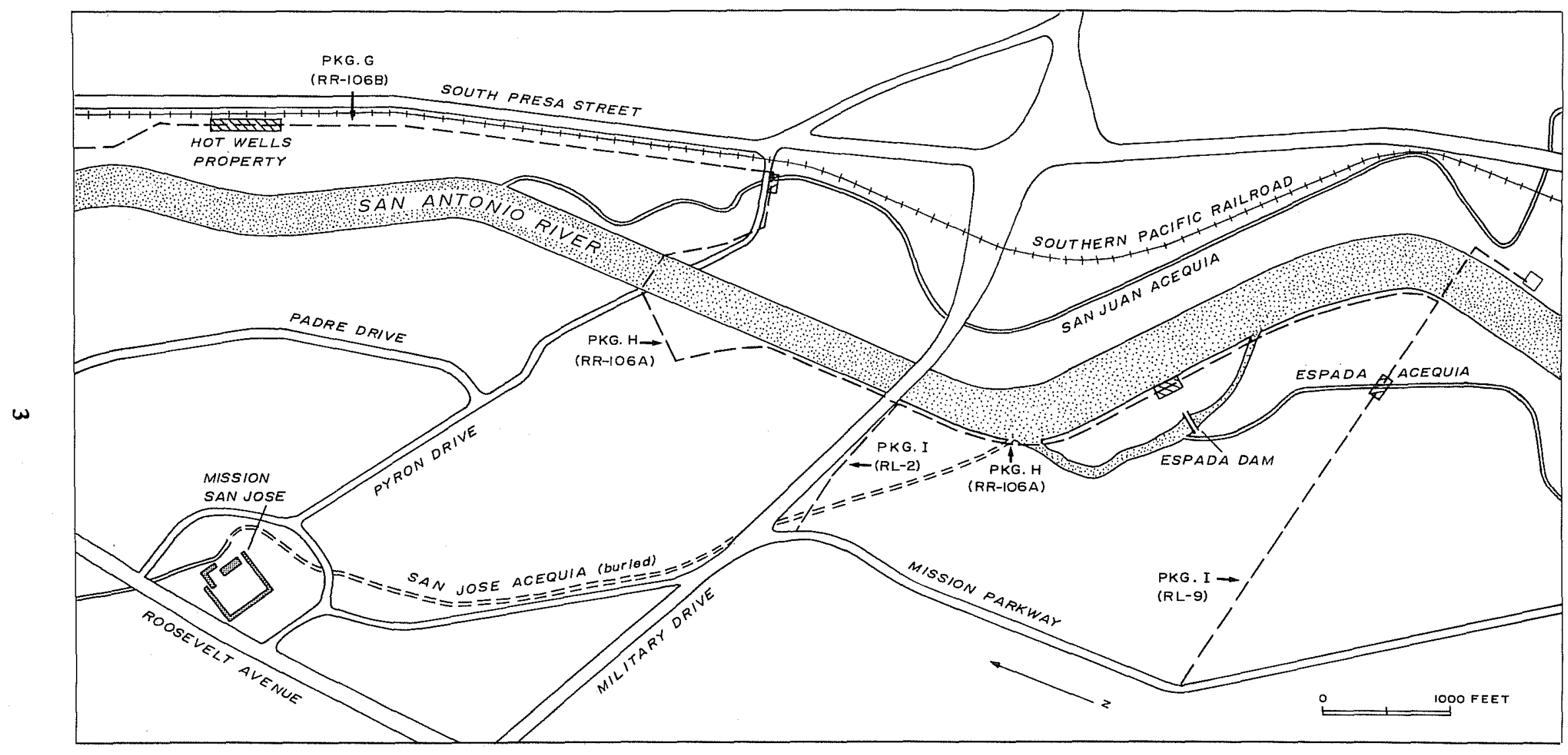

Figure 2. Pipeline Locations. 
Antonio businessmen constructed a larger bathhouse and a large hotel on property across the road from the hospital. This became a popular resort and health spa and attracted visitors from all over the country. A number of prominent visitors and the filming of several movies there brought notoriety to the hotel.

The onset of Prohibition and the Depression brought hard times for the Hot Wells Hotel. The property was sold to the Christian Scientists in 1923 and converted into a school. In 1925, the hotel was destroyed by fire. The bathhouse continued in use by local people, and a tourist court was built over the cleared site of the hotel. The structures are now abandoned and vandalized, the bathhouse is near collapse, and a caretaker and a few families live in trailers on the site.

\section{MONITORING}

\section{Package G}

During the months of April through July 1988, a sewer line trench ca. 12 feet wide and 20 feet deep was excavated from Pyron Road north through the property of the State Hospital and the Hot Wells Hotel property, parallel to the Southern Pacific Railroad track (Fig. 3). The excavation was monitored on a regular basis by the authors, who visited the area weekly. No cultural materials were revealed, either on the surface when it was cleared for the line nor in the trench walls or backdirt as excavation continued through the area of the state property and the southern part of the Hot Wells Hotel property.

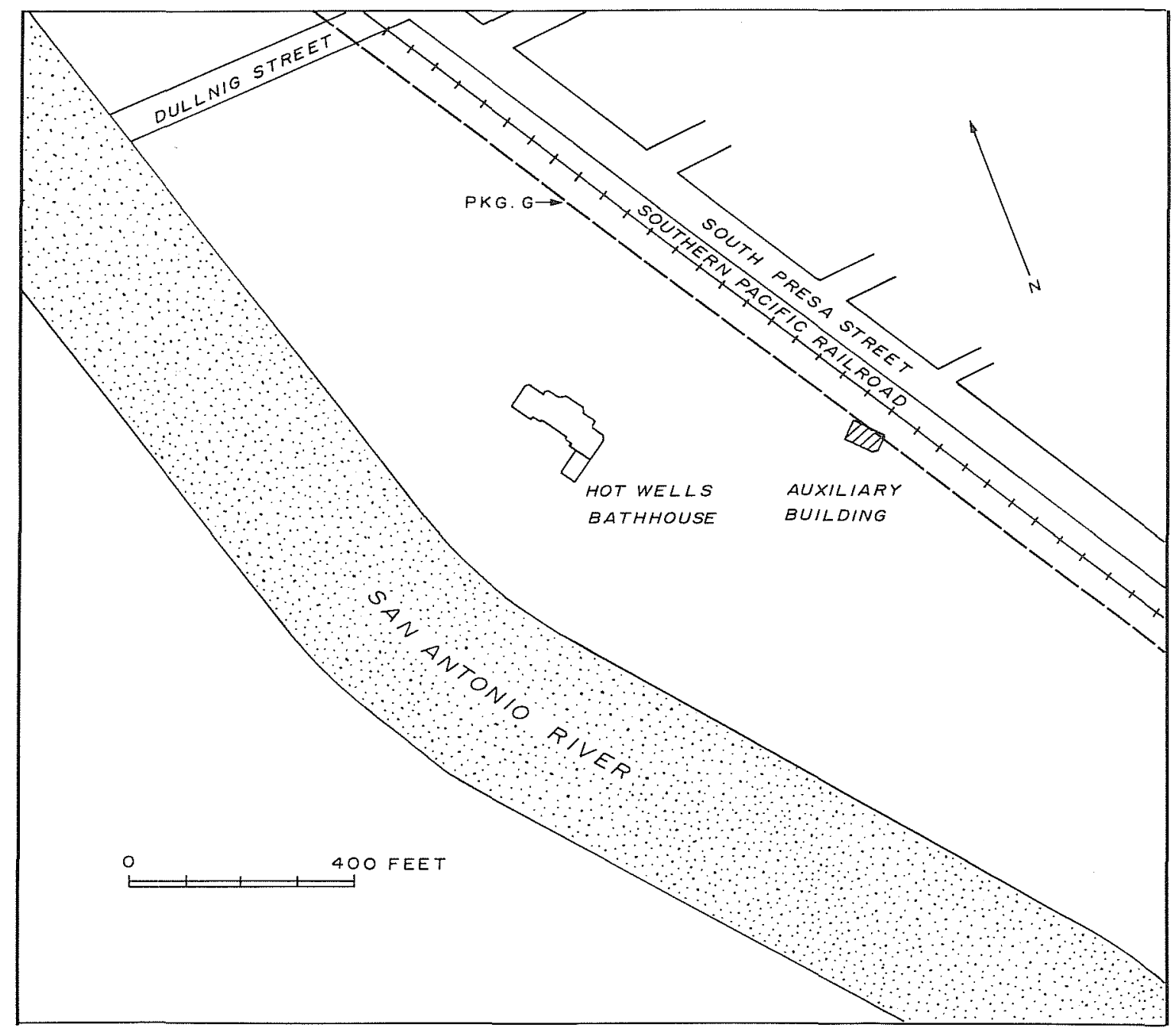

Figure 3. Location of the Auxiliary Building on the Hot Wells Hotel Property. 
In April 1984, the CAR conducted an archaeological and historic assessment of the Hot Wells Hotel property (41 BX 237), a National Register site on South Presa Street in south San Antonio (Fox and Highley 1985). During the course of those investigations the outline of a brick foundation wall was discovered in the area immediately to the east of the hotel location (Fig. 3 ). When traced out it proved to be a rectangular structure with the southeast corner truncated. It was noted at the time that the foundation was of brick identical to those found in association with the hotel foundations, but that these foundation walls varied in thickness. It was assumed to be contemporary with the construction of the hotel (1900). The purpose of the structure was not known, and no references to it had been found, but due to its location between the hotel and the railroad tracks, it was conjectured that it may have been a railroad station. It was recommended that the entire area be avoided if possible, and if not possible, close coordination be maintained with the State Historic Preservation Officer.

During the monitoring of Package G, it became apparent that the path of the trench would impact upon the auxiliary building (Fig. 3) on the Hot Wells Hotel site. After lengthy discussion with the State Historic Preservation Officer, it was decided that the trenching would be permitted to continue, but that representatives of the CAR were to monitor and record the operation. In August 1988, as the trench approached the structure, the project engineers notified the CAR to be on site. Three staff archaeologists arrived on the scene as the trench was approximately 40 feet south of the structure.

The 12-foot-wide trench encountered the southeast wall of the structure 12 feet from the northeast corner and exited the north wall 14 feet from the northwest corner (Fig. 4). The dirt fill at

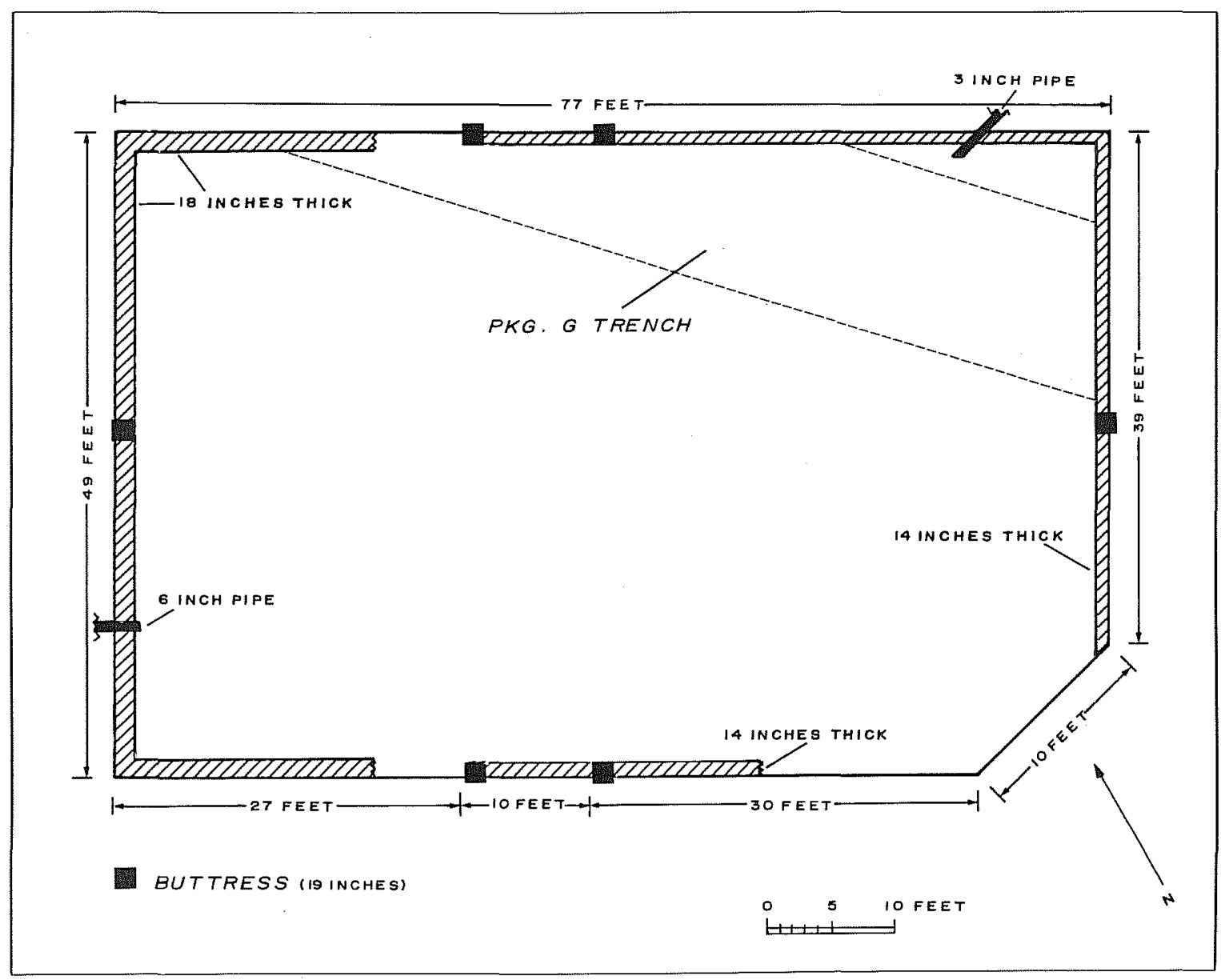

Figure 4. Plan of the Auxiliary Building. 
the northeast corner collapsed into the trench allowing a view of the interior of the structure. The interior of the wall was sealed with a thin coating of cement, upon which a water line was visible ca. 44 inches above a three-inch concrete floor (Fig. 5,a). The brick patterning (Fig. 5,b) was exactly the same as that utilized in construction of the Hot Wells bathhouse. The floor of the structure sloped from 40 inches in depth from the water line on the southeast to 45 inches on the northwest. This information, coupled with the visible water line, seems to indicate that the structure served as a bathing pool. Further supporting this conclusion is the increased buttressing and wall thickness at the deeper end to contain the water pressure. The exposed portion of the structure was extensively photographed, and elevations were recorded by the project engineers. All data and photographs are on file at the CAR.

\section{$\underline{\text { Package } \mathbb{H}}$}

In October 1987, at the request of the National Park Service, the authors monitored the excavation of a sewer line trench that ran to the east of the east end of the Espada dam (Fig. 2). The trench revealed that the area consists of river gravels to a depth of ca. 20 feet. No evidence was present for any buried structure related to the construction of the dam.

In January 1988, Fox met with representatives of the PD VA Group and the Department of Environmental Management at the Pyron Road crossing of the San Juan acequia (Fig. 2) to discuss the location of the sewer line as it was to be bored beneath the acequia. Subsequent trips were then made to the site to monitor the boring process (see description of process under "Package I" section). Twenty-foot-deep pits were dug at points 10 to 15 feet outside each bank of the acequia, and a pipe was installed in a hole machine-bored beneath the channel. No historic or prehistoric cultural materials were encountered during this process.

\section{Package I}

On August 26, 1988, the CAR was notified that the project, Package I, was prepared to bore under the Espada acequia, and monitoring was required. The location of the bore was on the west bank of the San Antonio River to the south of the Espada dam and north of Ashby Road (Fig. 2). When the CAR representative arrived, the bore pit had already been excavated. The operation required an area of dirt to be removed approximately $30 \times 60$ feet to a depth of approximately 20 feet. In this pit a Richmond $42-45$ borer was installed. This enabled the crew to bore a 36 -inch steel encased channel under the acequia. The acequia had been reported to be a double channel at this point, however, only one channel existed at the time of the inspection. It was unlined, approximately six feet wide and three feet deep. Boring operations continued until the evening when work was terminated for the weekend. Operations began again on Monday and continued until Tuesday afternoon, August 30, when the bore penetrated the wall of the pit excavated on the west side of the acequia, a length of $70 \mathrm{feet}$. Monitoring was concluded at that time.

Unfortunately, neither the engineers nor the contractor notified the CAR archaeologists when the trench for Package I crossed the area where the San José acequia is buried. Therefore, we have no information to report on that operation.

\section{SUMMARY AND CONCLUSIONS}

More than 30 man days were spent in monitoring the excavation of sensitive areas of sewer lines installed within the Mission Parkway Historic/Archeological District. In places where the lines crossed the routes of mission acequias, they were successfully bored beneath the channel, causing no disturbance to the waterways (with the exception of the San José acequia). No artifacts were encountered during any of the monitoring operations. 


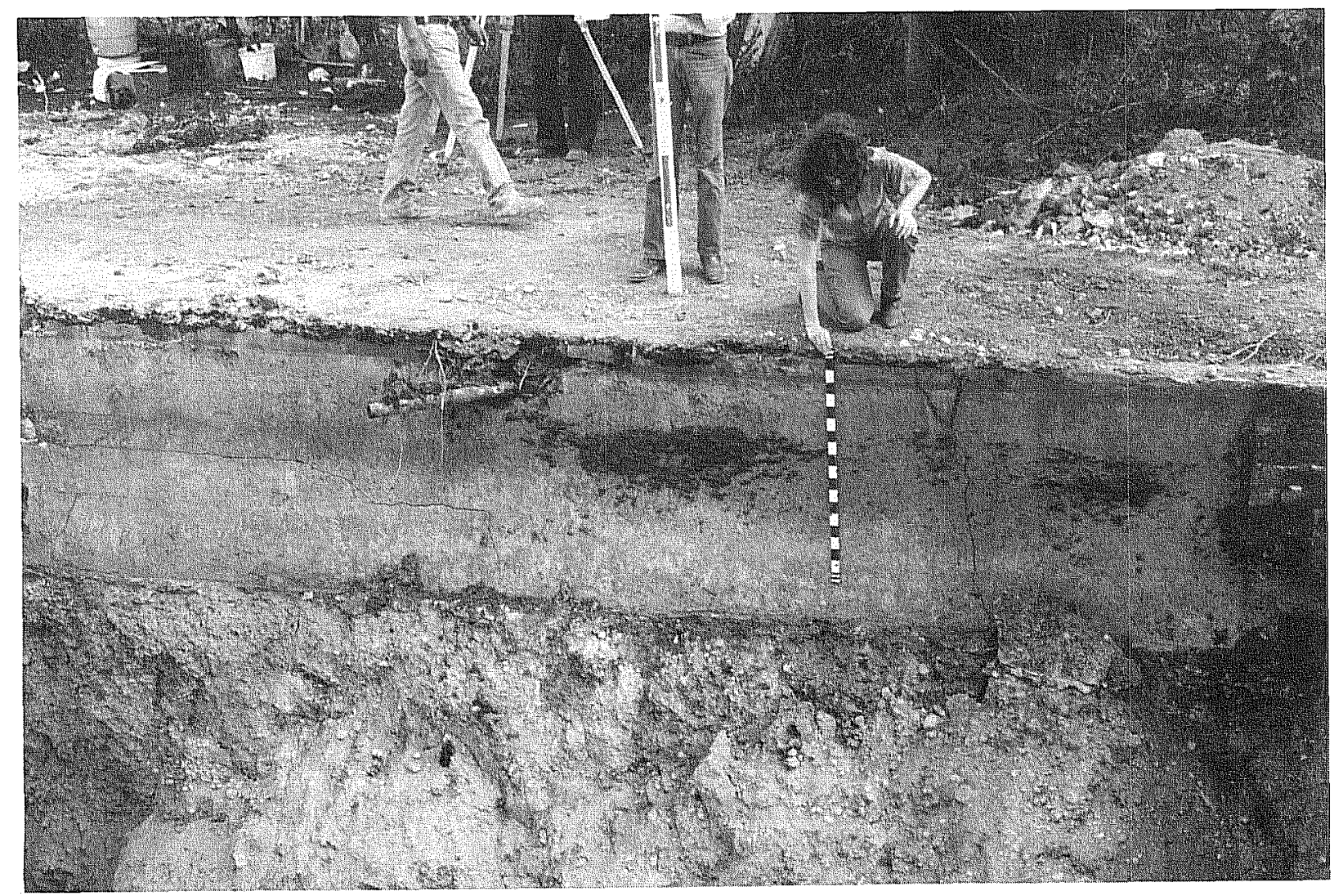

a

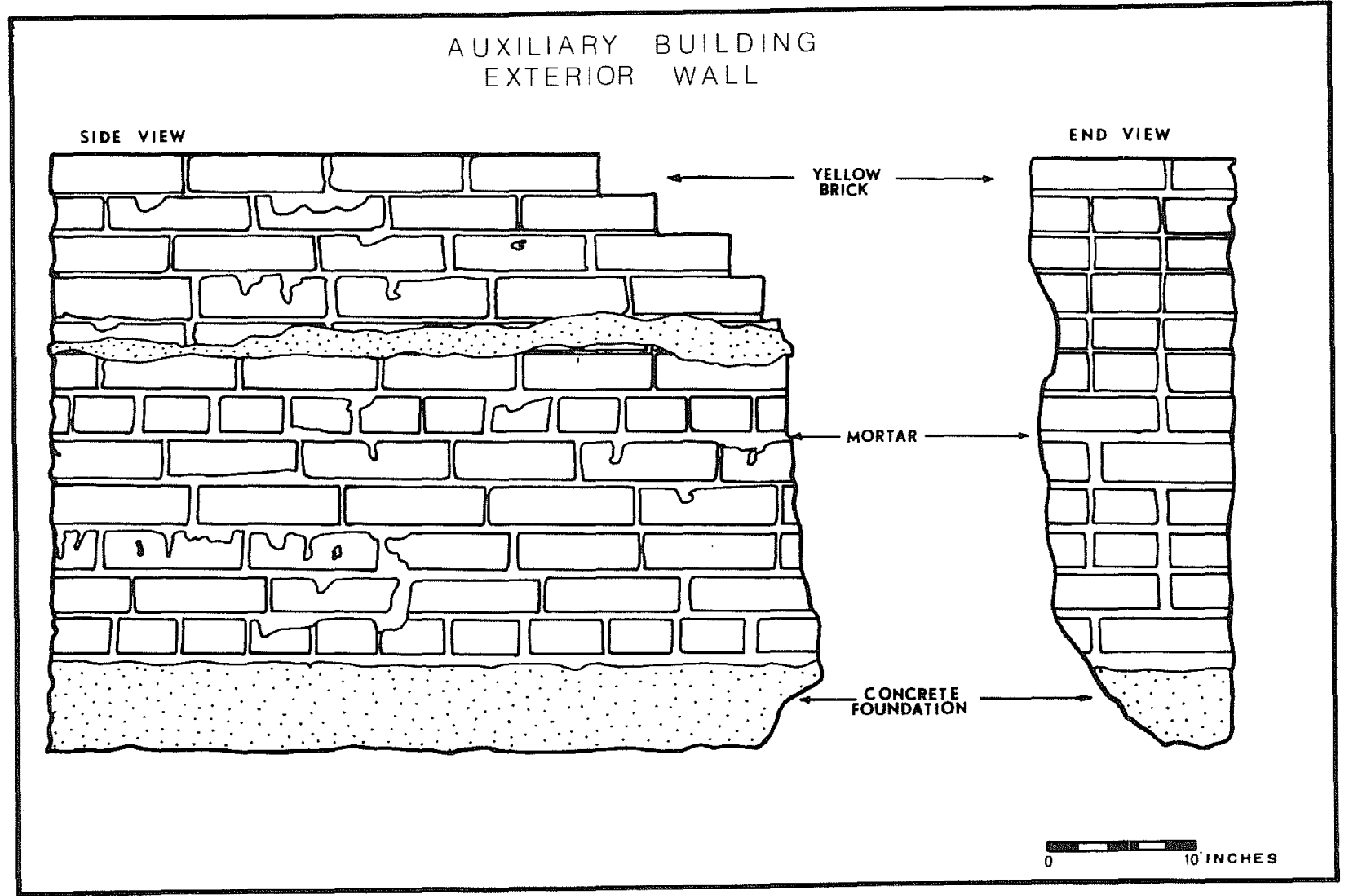

b

Figure 5. Construction Details of the Auxiliary Building. a, view of cement sealed interior wall of structure; b, brick construction exposed by the pipeline trench. 
No prehistoric or historic archaeological remains were encountered, except for the foundation of an auxiliary building to the Hot Wells Hotel. The cutting of the sewer trench across the southeast corner of this otherwise unidentified structure allowed the identification of the building as a bathing pool. No recommendations are forthcoming from this project for eligibility for sites for National Register status or State Archeological Landmark designation.

\section{REFERENCES CITED}

Assad, C.

1979 Additional Archaeological Survey for the San Antonio 201 Wastewater Treatment Project. Center for Archaeological Research, The University of Texas at San Antonio, Archaeological Survey Report 73.

Clark, J. W., Jr.

1978 Mission San José y San Miguel de Aguayo: Archeological Investigations, December 1974. Texas Historical Commission, Archeological Report 29.

Cox, I. W.

1978 Archaeological Monitoring of the San José Acequia (41 BX 267), Wastewater Facilities Improvements Program, San Antonio, Texas. Center for Archaeological Research, The University of Texas at San Antonio, Archaeological Survey Report 175.

Cox, I. W., A. A. Fox, D. Hafernik, and K. Scott 1989 Archaeological Investigation of the San Juan Dam, 41 BX 266, Bexar County, Texas. Center for Archaeological Research, The University of Texas at San Antonio, Archaeological Survey Report 179.

Fox, A. A.

1977 An Archaeological Assessment of the San Antonio 201 Wastewater Treatment Project. Center for Archaeological Research, The University of Texas at San Antonio, Archaeological Survey Report 41.
Fox (continued)

1979 Plan for Mitigation of Archaeological Sites, San Antonio 201 Wastewater Treatment Project. Center for Archaeological Research, The University of Texas at San Antonio, Archaeological Survey Report 75.

Fox, A. A. and C. L. Highley

1985 History and Archaeology of the Hot Wells Hotel Site, 41 BX 237. Center for Archaeological Research, The University of Texas at San Antonio, Archaeological Survey Report 152.

Fox, A. A., A. J. McGraw, and F. Valdez, Jr.

1978 Archaeological Survey and Testing of Pipelines and Confluence Site, San Antonio 201 Wastewater Treatment Project. Center for Archaeological Research, The University of Texas at San Antonio, Archaeological Survey Report 66.

Hafernik, D. and A. A. Fox

1984 Archaeological Testing of Proposed Sewer Line Location at Mission San José. Center for Archaeological Research, The University of Texas at San Antonio, Archaeological Survey Report 138.

Rotchford, W. P.

n.d. Plan of the Acequias (Irrigation Ditches) of the Five Missions In and Near San Antonio, Texas, compiled from data in the Office of Stewart Title Guaranty Co. On file at the Center for Archaeological Research, The University of Texas at San Antonio.

Scurlock, D., A. Benavides, Jr., D. Isham, and J. W. Clark, Jr.

1976 An Archeological and Historical Survey of the Proposed Mission Parkway, San Antonio, Texas. Office of the State Archeologist, Archeological Survey Report 17.

Snavely, R., M. Greco, and A. A. Fox

1984 Archaeological Assessments for the San Antonio 201 Wastewater Treatment Project: Surveys of Five Pipeline Routes and Testing at Site $41 \mathrm{BX}$ 333. Center for Archaeological Research, The University of Texas at San Antonio, Archaeological Survey Report 131. 